\title{
Groundwater recharge estimation using groundwater level fluctuation patterns in unconfined aquifer of Yogyakarta City, Indonesia
}

\author{
Wahyu Wilopo $^{1,2^{*}}$ and Doni P.E. Putra ${ }^{1,2}$ \\ ${ }^{1}$ Dept. of Geological Engineering, Faculty of Engineering, Gadjah Mada University, Yogyakarta \\ 55281, Indonesia \\ ${ }^{2}$ Center for Disaster Mitigation and Technological Innovation (GAMA-InaTEK), Gadjah Mada \\ University, Yogyakarta 55281, Indonesia \\ *Corresponding author: wilopo_w@ugm.ac.id
}

\begin{abstract}
Water demand in the world increases rapidly every year, especially in urban areas due to population growth and improved economic conditions. The largest freshwater source on earth is groundwater that can be utilized and easily obtained. However, the number of groundwater resources is very dynamic, depending on the recharge and discharge, including groundwater extraction. Increasing groundwater abstraction will cause a decline in groundwater level and seawater intrusion in the coastal area. Groundwater level fluctuation trends can be used to estimate groundwater recharge for optimum utilization. Therefore, this study aims to find the trend of groundwater level fluctuation related to rainfall to estimate the groundwater recharge in Yogyakarta City, Indonesia. The study was carried out by measuring the groundwater level of four monitoring wells that spread evenly in Yogyakarta City from 2011 to 2017 every month and comparing the result to monthly rainfall and annual groundwater abstraction from hotels in Yogyakarta City. The annual trend of rainfall and groundwater level fluctuation analysis using the nonparametric Mann-Kendall test and analyzing the trend's magnitude using the nonparametric Sen's method. The groundwater recharge was estimated by using the water table fluctuation (WTF) method. The study results showed that the trend of rainfall and groundwater level fluctuation is positive in the city's western and eastern parts. However, the groundwater level fluctuation in the city's central and southern parts is a negative trend due to groundwater over-exploitation by hotels. Groundwater recharge is estimated at around 158 up to $538 \mathrm{~mm} /$ year based on the WTF method. Higher groundwater recharge was identified in the city's central and eastern parts due to the high contribution from urban wastewater recharge.
\end{abstract}

Keywords: Groundwater fluctuation; groundwater recharge; rainfall trend; monitoring well; WTF method.

\section{Introduction}

Water is the most important natural resource used daily for different purposes (Gatto \& Lanzafame, 2005). Water demand from year to year shows a very large increase due to population and economic growth. On the other hand, there is a decline in water resources and water quality due to anthropogenic activities. In 2050, it is estimated that around 6 billion people will have trouble having access to clean water sources (WWAP, 2019). Improved clean water supply and water management, applying appropriate technology for water treatment, and water resources conservation 
may prevent future water shortages (Boretti \& Rosa, 2019). Many people use groundwater resources instead of surface water because of various advantages, namely better quality and more stable quantity; however, the costs for exploration and exploitation for groundwater are more expensive than surface water (Winter et al., 1998; Velis et al., 2017).

Groundwater level fluctuations vary greatly in space and time (Lutz et al., 2015; Manna et al., 2019). Several factors, including geology, topography, climate, and anthropogenic activities, influence the fluctuation (Apaydin, 2010; Healy \& Cook, 2012). The rainfall pattern is the most contributing factor to groundwater fluctuation (Abdullahi \& Garba, 2015). The long-term Spatio-temporal variation of groundwater level is highly influenced by the water use and recharge (Zhou et al., 2016). The groundwater table analysis in the spatialtemporal patterns can be used as a conjunctive water management tool (Vasconcelos et al., 2017). Groundwater level fluctuation analysis is also very useful for determining the magnitude of long-term groundwater recharge changes due to climate or land-use change (Healy \& Cook, 2002; Dinka et al., 2013).

Groundwater recharge calculations can be performed in several ways using the following techniques, namely techniques based on an unsaturated-zone study, techniques based on the surface-water study, water budget, and physical techniques (Scanlon et al., 2002). One method of physical techniques is the water-table fluctuation (WTF) method. The WTF method is based on the concept that groundwater recharge results from an increase in groundwater level due to previous rainfall. This method is the most accurate method for estimating groundwater recharge compared to laboratory tests to determine water retention curves and pumping tests (Crosbie et al., 2005). This method has been widely used in various studies relating to groundwater recharge (Sophocleous, 1991; Healy \& Cook, 2002; Varni et al., 2013; Cai \& Ofterdinger, 2016). The WTF method is suitable for calculating groundwater recharge in shallow unconfined aquifers where the groundwater level is strongly influenced by rainfall.

Most Indonesian people use groundwater as the primary source for daily needs, such as Yogyakarta City. Yogyakarta City is one of Indonesia's most populous cities, with a population density in 2017 around 13,007 people $/ \mathrm{km}^{2}$ (BPS-Statistics of Yogyakarta City, 2018). Yogyakarta City's geology is influenced by the subduction of the Indian Australian oceanic plates below the Eurasian continental plate in the south and active volcano in the north. Yogyakarta City is composed of sand materials from the Merapi volcano eruption, located around $30 \mathrm{~km}$ north of the city. Three major rivers, which the headwaters are in the Merapi volcano in the north of Yogyakarta, divide Yogyakarta City, namely the Winongo River, the Code River, and the Gajahwong River. These rivers have high fluctuation discharges and low water quality. Therefore, groundwater is used as the main source to support all the daily water needs. Most people in Yogyakarta City use shallow wells or deep wells for groundwater abstractions. This is due to the limited network of water from Municipal Waterworks (PDAM), which can only supply 32,500 customers $(30.7 \%)$ of city residents (BPS-Statistics of Yogyakarta City, 2018). PDAM in Yogyakarta City relies mainly on water sources from drilled wells and springs from the Sleman Regency located north of the city. Yogyakarta City is an academic city and is one of the tourist destinations in Indonesia. Many local and international tourists visit this city every year. Therefore, in the last five years, many infrastructures have been built to support public facilities, especially hotels (BPS-Statistics of Yogyakarta City, 2018). Most of these public facilities also use 
groundwater from private wells as a water supply source due to limited water supply from the PDAM. This condition can cause a long-term decline in groundwater level and water scarcity in the city. Fluctuations can also cause a decrease in the groundwater level due to seasonal changes. Understanding the pattern of groundwater fluctuation in the long term, which is influenced by groundwater utilization and recharge, is very important for managing groundwater resources to guaranty sustainable development.

\section{Methodology}

The research was conducted in Yogyakarta City, Yogyakarta Special Region Province, Indonesia, as shown in Figure 1. The city has an area of $32.5 \mathrm{~km}^{2}$ or $1.02 \%$ of the province. This area is located at the foot of the southern slope of Merapi volcano, with a relatively flat topography. The area is composed of sediments resulting from the Merapi volcano's eruption with sand dominance from the Yogyakarta formation (Mac Donald \& Partners, 1984). This formation extends from the slopes of Merapi volcano to the southern area of Bantul. The materials are dominated by a boulder, pebble, gravel, sand, and lahar deposit in the northern area, while its grain size becomes finer in the southern area. The thickness of the formation is around 150 meters in the city's central part, composed of medium sand with a sub-angular to rough shape and clay lenses. The sand formation is a good aquifer and consists of multilayer aquifers (Mac Donald \& Partners, 1984). This upper aquifer has a hydraulic conductivity of $7.8 \mathrm{~m} /$ day, storativity between 0.03 to 0.20 , and a specific yield of 0.2 (Putra, 2007), whereas the bottom aquifer consists of sandy gravel with a high hydraulic conductivity value and high productivity.

Stratigraphy data determined aquifer types. There are 63 well log data from Yogyakarta City and its surrounding area to develop the research area's stratigraphy model. The hydraulic permeability test was conducted in the ten wells located in the central part of the city.

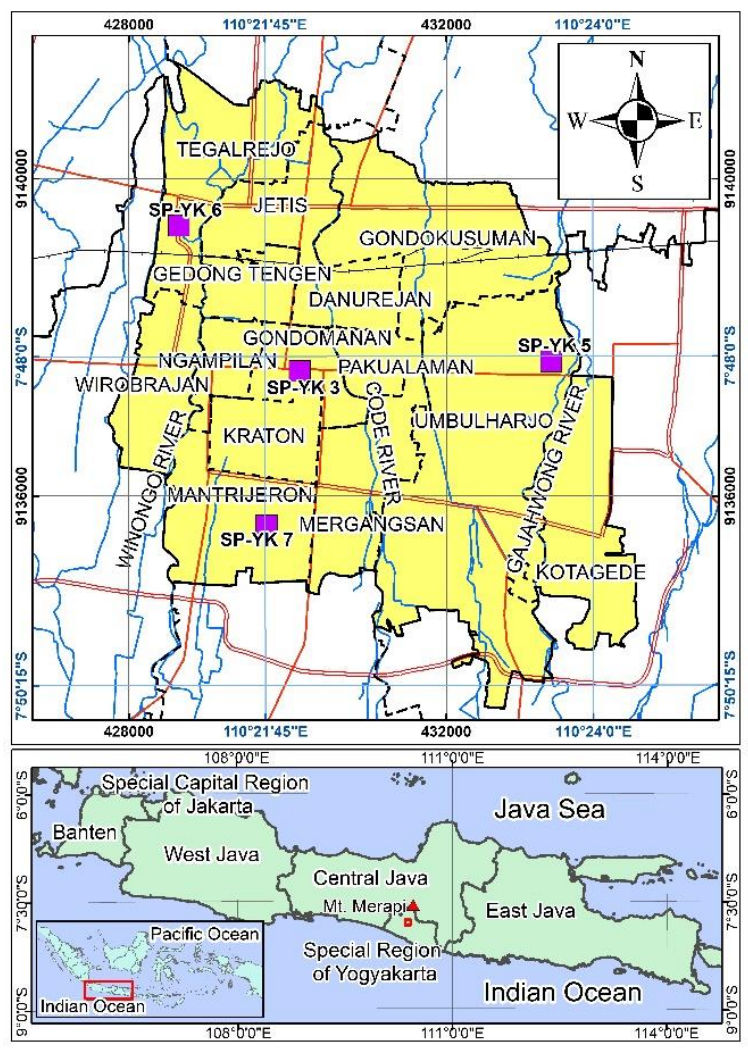

Fig. 1. The location of monitoring wells (purple square signs) in Yogyakarta City, Indonesia.

Groundwater level measurements were carried out in four monitoring wells spread evenly in the Yogyakarta Special Region Province Government's study area, as seen in Figure 1. SP-YK3 monitoring well is located in Gondomanan Sub-district (central part), SP-YK5 monitoring well in Umbulharjo Subdistrict (eastern part), SP-YK6 monitoring well in Tegalrejo Sub-district (western part), and SP-YK7 monitoring well in Mantrijeron Sub-district (southern part). The monitoring well has an average depth of 50 meters, with a screen's installation starting at a depth of 20 meters to 40 meters.

Measurements were conducted every month on the $1^{\text {st }}$ of every month for seven years from 2011 to 2017 . The groundwater in 
the monitoring wells was measured by an automatic water level recorder (AWLR). The monthly rainfall data from 2011 to 2017 is obtained from the Meteorological, Climatological, and Geophysical Agency of Indonesia (BMKG, 2018).

The analysis of rainfall data patterns and groundwater level fluctuations used the nonparametric Mann-Kendall test, and the analysis of the magnitude patterns used Sen's nonparametric method (Gilbert, 1987; Pohlert, 2016). The method has been widely used to analyze hydrological data consisting of time series data (Salmi et al., 2002; Ahmad et $a l ., 2015)$. The amount of annual values in the research data series is symbolized by $n$. The Mann-Kendall $S$ statistical test is calculated using the following formula (Gilbert, 1987):

$$
S=\sum_{k=1}^{n-1} \sum_{j=k+1}^{n} \operatorname{sgn}\left(x_{j}-x_{k}\right)
$$

where $\mathrm{x}_{\mathrm{j}}$ and $\mathrm{x}_{\mathrm{k}}$ are the annual values in years' $\mathrm{j}$ and $\mathrm{k}, \mathrm{j}$ is higher than $\mathrm{k}$, respectively, and

$$
\operatorname{sgn}\left(x_{j}-x_{k}\right)=\left\{\begin{array}{l}
1, \text { if } x_{j}-x_{k}>0 \\
0, \text { if } x_{j}-x_{k}=0 \\
-1, \text { if } x_{j}-x_{k}<0
\end{array}\right.
$$

If the data (n) is equal or less than $9, \mathrm{~S}$ 's absolute value is then directly compared to the theoretical distribution of $\mathrm{S}$ derived by Mann and Kendall (Gilbert, 1987; Salmi et al., 2002). A positive $S$ value indicates an upward pattern (positive) while a negative value indicates a downward. Sen's nonparametric method is used to estimate the exact slope of the existing pattern, assuming that the pattern follows a linear regression. The Sen's (f $(t))$ equation is as follows:

$$
f(t)=Q t+B
$$

Where $\mathrm{Q}$ is the slope and B is a constant value. To obtain the estimated slope $(Q)$ in equation (3), the slope for all paired data is calculated with the following equation

$$
Q_{i}=\frac{x_{j}-x_{k}}{j-k}
$$

where $\mathrm{j}$ value is higher than $\mathrm{k}$.

The groundwater intake is calculated using the following formula (Healy and Cook, 2002):

$$
R=S_{y} \frac{d h}{d t}=S_{y} \frac{\Delta h}{\Delta t}
$$

Where $\mathrm{h}$ is water-table height, $\mathrm{t}$ is time, and Sy is a specific yield. The WTF method is used in this research because groundwater levels are carried out regularly and over a long period in the monitoring wells. This method is also beneficial to learn about groundwater recharge variations temporally and spatially.

\section{Results and Discussion}

The fence diagram stratigraphy shows that the Merapi sand deposit thickness in the study area reaches more than 100 meters and has a dominant particle size of sand, as shown in Figure 2. In the upper layer, up to 15 meters depth is dominated by sand with silt lenses in some areas in which the groundwater level is located in this layer. There are some lenses of clay and breccia found in the central and southern parts of the city. A deeper layer of more than 50 meters was mostly dominated by sand interbedded with clay. By looking at the stratigraphic data, it can be concluded that the aquifers in the upper layer of Yogyakarta City are unconfined. The hydraulic permeability of aquifer layers ranges from $2.46 \times 10^{-2} \mathrm{~m} /$ day to $3.08 \times 10^{-3} \mathrm{~m} /$ day. 


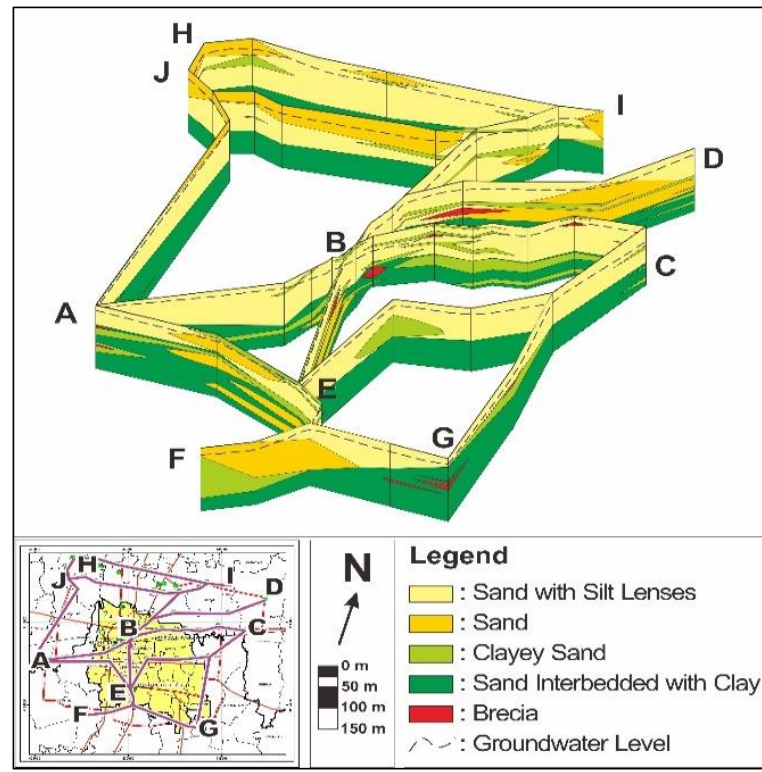

Fig. 2. The stratigraphic fence diagram of Yogyakarta City.

\subsection{Rainfall and groundwater level fluctuation pattern}

The rainfall pattern from 2011 to 2017 produces the $\mathrm{S}$ value of the Mann-Kendall nonparametric method of 3 by using equation (1) and (2) while the slope of the linear regression equation with the nonparametric Sen's method (equation 3 and 4) obtains a Q value of 9.63 and a constant (B) of 123.82 as shown in Table 1. According to the results of nonparametric Mann-Kendall and Sen's methods, the city's rainfall patterns have a positive trend with increasing intensity from year to year, as shown in Figure 3. The average of increasing rainfall intensity is 8.25 $\mathrm{mm} /$ year.

The monthly groundwater level fluctuation in the city shows different patterns. The Mann-Kendall nonparametric method's $S$-value shows the negative value for groundwater level fluctuation at SP-YK3 and SP-YK7 monitoring wells, while SPYK5 and SP-YK6 monitoring wells show a positive trend as summarized in Table 1. Increasing groundwater levels in SP-YK5 and SP-YK6 are $0.27 \mathrm{~m} /$ year and 0.21 m/year, respectively. However, SP-YK3 and SP-YK7 monitoring wells have a decreasing groundwater level of $0.11 \mathrm{~m} /$ year and 0.26 $\mathrm{m} /$ year, respectively. The groundwater level response due to rainfall shows a similar pattern in all monitoring wells, as shown in Figure 3. The response to the decrease in groundwater level due to the absence of rainfall is much faster to reach its peak with the time ranging from 1 to 2 months, while the response to the increase in groundwater level due to rainfall ranges from 2 to 4 months to reach its peak. For example, in the SP-YK5 well, the rain stopped in September 2014, but the deepest groundwater level was reached in November 2014. Conversely, when it rained with the highest intensity in January 2015, the shallow groundwater level peak was May 2015. The most significant fluctuations occurred at the end of 2014 to early 2015 at the SP-YK3, SP-YK5, and SP-YK7 monitoring wells, while at the SP-YK6 well, it occurred in late 2012 to early 2013.

\subsection{Groundwater recharge}

The groundwater recharge in the study area is divided into four zones based on the locations monitoring wells. The groundwater recharge estimation was determined from the peak data of the highest groundwater level with the extrapolation line of the previous groundwater level decrease in each well occurring in the same period. Therefore, the data was used to calculate $\Delta \mathrm{h}$ from April 1, 2014, to May 1, 2015, as shown in Figure 4. The $\Delta \mathrm{h}$ values obtained from the monitoring graph well SP-YK3, SP- YK5, SP-YK6, and SP-YK7 are $13.47 \mathrm{~m}, 7.7 \mathrm{~m}, 3.95 \mathrm{~m}$, and 4.72 $\mathrm{m}$, respectively. With a specific yield value of 0.2 (Putra, 2007) and by using equation 4 , the groundwater recharge at each monitoring well of SP-YK3, SP- YK5, SP-YK6, and SPYK7 are estimated at $538.8 \mathrm{~mm} /$ year, 308 $\mathrm{mm} /$ year, $158 \mathrm{~mm} /$ year, and $188.8 \mathrm{~mm} /$ year, respectively. 
Table 1. Mann- Kendall Nonparametric Test and Sen's Slope for rainfall and groundwater level fluctuation data.

\begin{tabular}{|c|c|c|c|c|c|c|c|c|c|c|c|c|c|c|}
\hline & Test & Jan & Feb & Mar & Apr & May & Jun & Jul & Aug & Sep & Oct & Nov & Dec & Annual \\
\hline \multirow{3}{*}{ Rainfall } & $\mathrm{S}$ & 3 & -11 & 1 & 7 & 1 & -3 & 8 & 8 & 4 & 5 & 0 & 5 & 3 \\
\hline & Q & 8.00 & -28.00 & 8.00 & 25.50 & 10.00 & -10.00 & 1.84 & 6.35 & 0.00 & 0.00 & 0.00 & 52.58 & 9.63 \\
\hline & B & 393.00 & 424.00 & 270.00 & 121.50 & 176.00 & 118.00 & 0.00 & 0.00 & 0.00 & 0.00 & 36.00 & 117.42 & 123.82 \\
\hline \multirow{3}{*}{$\begin{array}{c}\text { Monitoring } \\
\text { Well } \\
\text { SP-YK3 } \\
\text { (Central) }\end{array}$} & S & -13 & -7 & -3 & -12 & -11 & -9 & -7 & -7 & -5 & -5 & 1 & 1 & -5 \\
\hline & Q & -0.49 & -0.22 & -0.24 & -0.33 & -0.27 & -0.22 & -0.13 & -0.10 & -0.13 & -0.12 & 0.02 & 0.10 & -0.13 \\
\hline & B & -7.99 & -8.68 & -8.63 & -7.13 & -7.90 & -8.45 & -9.42 & -9.66 & -9.90 & -9.78 & -9.82 & -9.70 & -9.33 \\
\hline \multirow{3}{*}{$\begin{array}{c}\text { Monitoring } \\
\text { Well } \\
\text { SP-YK5 } \\
\text { (Eastern) }\end{array}$} & $\mathrm{S}$ & 1 & 4 & 12 & 13 & 6 & 5 & 11 & 9 & 11 & 13 & 13 & 15 & 5 \\
\hline & Q & 0.03 & 0.19 & 0.32 & 0.38 & 0.26 & 0.20 & 0.29 & 0.27 & 0.38 & 0.42 & 0.46 & 0.47 & 0.31 \\
\hline & B & -7.03 & -7.19 & -7.19 & -7.48 & -7.23 & -7.40 & -8.09 & -7.93 & -8.46 & -8.81 & -8.88 & -8.60 & -7.93 \\
\hline \multirow{3}{*}{$\begin{array}{c}\text { Monitoring } \\
\text { Well } \\
\text { SP-YK6 } \\
\text { (Western) }\end{array}$} & $\mathrm{S}$ & 7 & 3 & 5 & 8 & 9 & 3 & 7 & 9 & 13 & 15 & 13 & 17 & 13 \\
\hline & Q & 0.37 & 0.16 & 0.16 & 0.24 & 0.19 & 0.07 & 0.12 & 0.19 & 0.36 & 0.40 & 0.49 & 0.59 & 0.22 \\
\hline & B & -6.82 & -6.82 & -7.03 & -7.34 & -6.72 & -6.91 & -7.37 & -7.67 & -8.46 & -8.53 & -8.59 & -8.45 & -7.22 \\
\hline \multirow{3}{*}{$\begin{array}{c}\text { Monitoring } \\
\text { Well } \\
\text { SP-YK7 } \\
\text { (Southern) }\end{array}$} & $S$ & -19 & -15 & -15 & -13 & -13 & -19 & -13 & -15 & -9 & -11 & 3 & 5 & -13 \\
\hline & Q & -0.61 & -0.45 & -0.41 & -0.22 & -0.32 & -0.44 & -0.36 & -0.37 & -0.14 & -0.23 & 0.03 & 0.12 & -0.30 \\
\hline & B & -1.74 & -2.10 & -2.08 & -2.48 & -2.09 & -2.16 & -2.79 & -3.32 & -4.21 & -4.28 & -4.33 & -4.23 & -2.85 \\
\hline
\end{tabular}

Note: - S: Mann-Kendall value; Q: the slope Sen’s regression; B: Constanta value of Sen's regression - The significance level $(\alpha)$ of $S$ is 0.2

\section{Discussion}

The monthly rainfall data from 2011 to 2017 shows a positive trend. Increasing monthly rainfall is possible due to the impact of global climate change, where several regions in Southeast Asia show a pattern of increasing precipitation from year to year (Endo et al., 2019). An increase also followed the increase in monthly rainfall from 2011 to 2017 in the groundwater level in the eastern and western parts of Yogyakarta city. Increased groundwater recharge due to higher rainfall and constant groundwater abstraction will result in a higher groundwater level. This is following previous studies which showed an increase in the groundwater level rise an average of about 3 meters in the Yogyakarta City area from the comparison of groundwater levels in 1985 and 2015, although some places had a decrease in the groundwater levels, such as in the southern part of the city (Manny et al., 2016).

Meanwhile, in the city's central and southern parts, groundwater level shows a reversal of rainfall patterns. The trend of decreasing groundwater level patterns in this area is probably due to the increase of groundwater extraction being higher than groundwater recharge. The number of hotels in the city's central and southern parts is more than 100 hotels in 2011 in each area. There was a rapid development until 2017, reaching more than 150 hotels, which are more numerous than the eastern and western regions, as shown in Table 2. Therefore, it needs to increase groundwater recharge by providing renewable groundwater resources in this area (Mohammad et al., 2016). Yogyakarta City has a small area with similar rainfall characteristics, the same type of rock with sand dominance (Figure 2), similar land use as an urban area with relatively flat topography. 

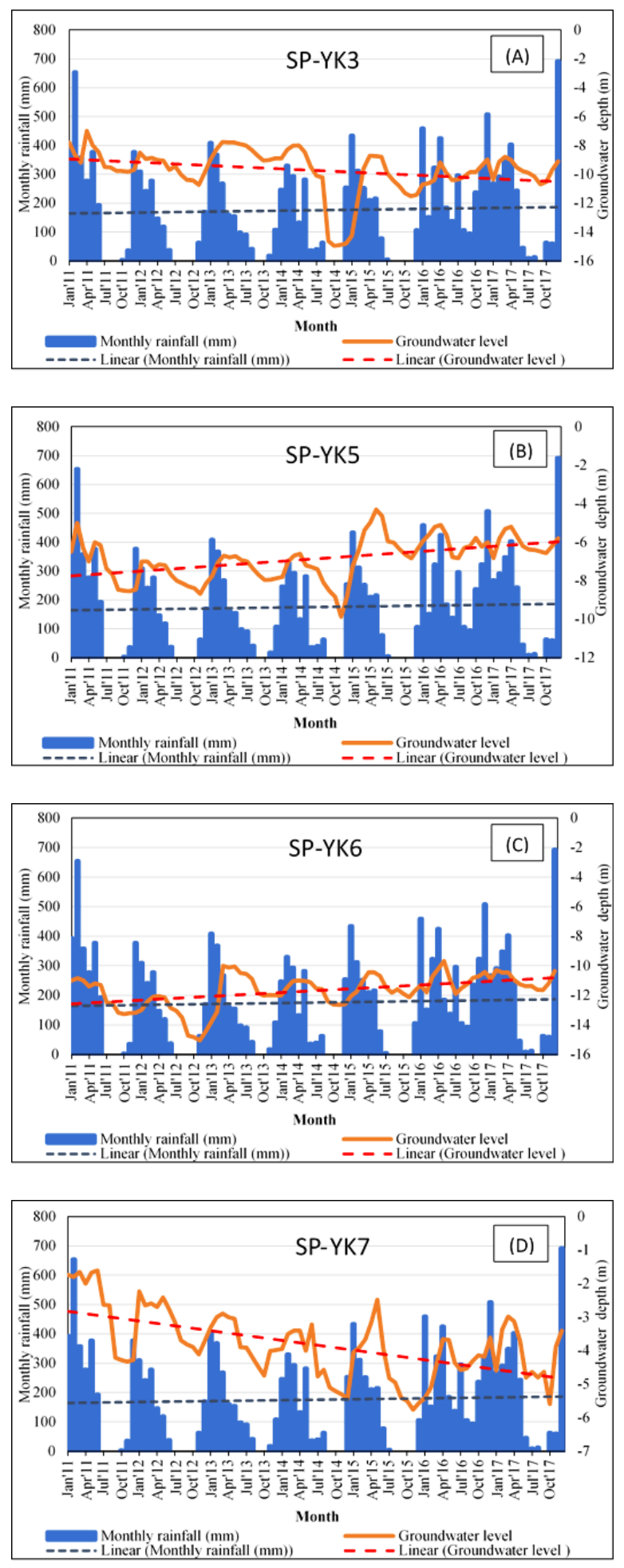

Fig. 3. Monthly rainfall versus groundwater level fluctuation in Yogyakarta City. (A) central part; (B) eastern part; (C) western part, and (D) southern part.
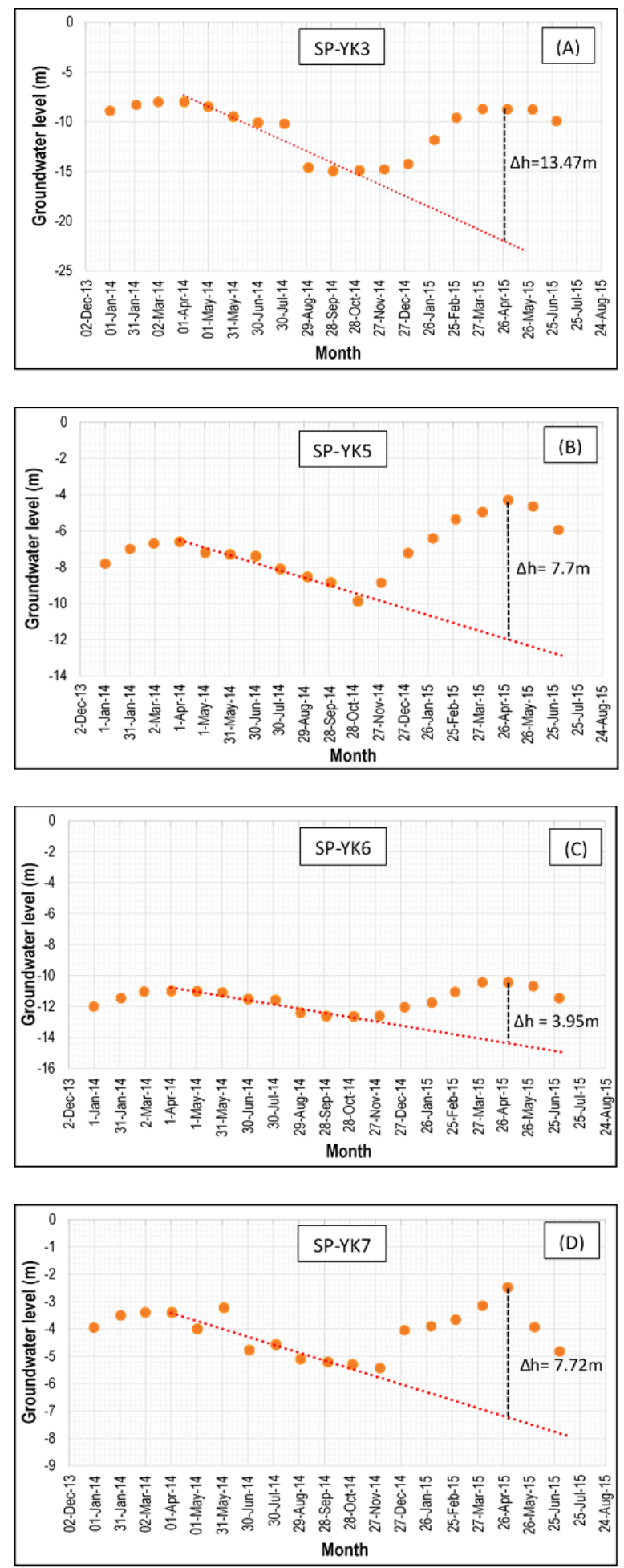

Fig. 4. The estimation of $\Delta \mathrm{h}$ for each monitoring well. (A) central part; (B) eastern part; (C) western part, and (D) southern part. 
Table 2. Hotel data in each area from 2011 to 2017 in Yogyakarta City.

\begin{tabular}{|c|c|c|c|c|c|c|c|c|c|c|c|c|c|}
\hline \multirow{2}{*}{ No. } & \multirow{2}{*}{ Area } & \multirow{2}{*}{ Sub-District } & \multicolumn{7}{|c|}{ Number of Hotel } & \multirow{2}{*}{$\begin{array}{l}\text { Population } \\
\text { in } 2017\end{array}$} & \multirow{2}{*}{$\begin{array}{l}\text { Area } \\
\left(\mathrm{km}^{2}\right)\end{array}$} & \multirow{2}{*}{$\begin{array}{c}\text { Population } \\
\text { density } \\
\left(/ \mathrm{km}^{2}\right)\end{array}$} & \multirow{2}{*}{$\begin{array}{l}\text { Annual } \\
\text { Recharge } \\
\text { (mm) }\end{array}$} \\
\hline & & & 2011 & 2012 & 2013 & 2014 & 2015 & 2016 & 2017 & & & & \\
\hline \multirow{4}{*}{1} & \multirow{4}{*}{$\begin{array}{l}\text { South } \\
\text { (SP- } \\
\text { YK7) }\end{array}$} & Mantrijeron & 41 & 44 & 46 & 47 & 46 & $*$ & 61 & 33,406 & 2.61 & \multirow{3}{*}{12,919} & \multirow{3}{*}{188.80} \\
\hline & & Kraton & 0 & 0 & 0 & 0 & 0 & $*$ & 11 & 17,575 & 1.40 & & \\
\hline & & Mergangsan & 59 & 61 & 61 & 67 & 65 & $*$ & 83 & 30,666 & 2.31 & & \\
\hline & & Total & 100 & 105 & 107 & 114 & 111 & & 155 & 81,647 & 6.32 & \multirow{7}{*}{26,502} & \multirow{7}{*}{538.80} \\
\hline \multirow{6}{*}{2} & \multirow{6}{*}{$\begin{array}{l}\text { Central } \\
\text { (SP- } \\
\text { YK3) }\end{array}$} & Danurejan & 23 & 22 & 27 & 30 & 30 & $*$ & 42 & 19,128 & 1.10 & & \\
\hline & & Gondomanan & 7 & 7 & 7 & 6 & 6 & $*$ & 16 & 13,697 & 1.12 & & \\
\hline & & Ngampilan & 7 & 7 & 7 & 9 & 9 & $*$ & 20 & 17,031 & 0.82 & & \\
\hline & & Gedongtengen & 137 & 136 & 123 & 121 & 116 & $*$ & 161 & 18,388 & 0.96 & & \\
\hline & & Jetis & 14 & 17 & 19 & 21 & 21 & $*$ & 31 & 23,983 & 1.70 & & \\
\hline & & Total & 188 & 189 & 183 & 187 & 182 & & 270 & 92,227 & 3.48 & & \\
\hline \multirow{5}{*}{3} & \multirow{5}{*}{$\begin{array}{l}\text { Eastern } \\
\text { (SP- } \\
\text { YK5) }\end{array}$} & Umbulharjo & 38 & 40 & 41 & 45 & 44 & $*$ & 55 & 90,775 & 8.13 & \multirow{5}{*}{24,009} & \multirow{5}{*}{308} \\
\hline & & Kotagede & 7 & 7 & 6 & 6 & 6 & $*$ & 9 & 37,055 & 3.07 & & \\
\hline & & Gondokusuman & 19 & 20 & 25 & 29 & 31 & $*$ & 45 & 47,461 & 3.99 & & \\
\hline & & Pakualaman & 13 & 13 & 13 & 13 & 14 & $*$ & 16 & 9,341 & 0.63 & & \\
\hline & & Total & 77 & 80 & 85 & 93 & 95 & & 125 & 184,632 & 7.69 & & \\
\hline \multirow{3}{*}{4} & Western & Tegalrejo & 7 & 7 & 10 & 10 & 10 & $*$ & 11 & 38,234 & 2.91 & \multirow{3}{*}{13,782} & \multirow{3}{*}{158} \\
\hline & YK6) & Wirobrajan & 15 & 15 & 15 & 15 & 15 & $*$ & 19 & 25,992 & 1.75 & & \\
\hline & & Total & 22 & 22 & 25 & 25 & 25 & & 30 & 64,226 & 4.66 & & \\
\hline
\end{tabular}

Note: $*$ data is not available

However, the value of groundwater recharge in each area is different based on the WTF method. The central part has the most significant groundwater recharge of 538.80 $\mathrm{mm} /$ year, followed by the eastern part of 308 $\mathrm{mm} /$ year, the southern part of 188.80 $\mathrm{mm} /$ year, and the western part $158 \mathrm{~mm} /$ year, as shown in Table 2.

The results are not much different from the previous studies, which stated that the groundwater recharge in Yogyakarta City is $151 \mathrm{~mm} /$ year (Wilopo et al., 2020). However, the central and eastern parts have a much higher value compared to the western and southern parts; this is probably due to the presence of an additional supply of infiltrated household wastewater into the ground. Almost all residents of the city use onsite wastewater treatment by septic tanks. The city's central and eastern parts' population density is more than 24,000 people $/ \mathrm{km}^{2}$, almost two times the western and southern population density. Therefore, the wastewater generated in the central and eastern parts will be much higher than in other areas.

The utilization of water from PDAM networks is only concentrated in the city's central and eastern parts (BPS-Statistics of Yogyakarta City, 2018), which provides additional water in the area. The volume of wastewater from households in the city is estimated at 59,182.48 $\mathrm{m}^{3} /$ day, considered an urban recharge to groundwater (Wilopo et al., 2021). Groundwater recharge from urban wastewater is also indicated by the high content of nitrate and $\mathrm{E}$ Coli bacteria in 
groundwater in the city, which shows pollution from the existing septic tanks (Putra, 2007; Fathmawati et al., 2018).

\section{Conclusions}

The rainfall pattern in Yogyakarta City had a positive trend from 2011 to 2017. The increase in rainfall is followed by a similar trend in groundwater level patterns in the western and eastern parts, whereas the city's central and southern parts show the opposite pattern. Decreasing groundwater level pattern in the central and southern parts is due to many groundwater extractions carried out by hotels. Therefore, it is necessary to have the policy limit groundwater extraction and develop artificial groundwater recharge to support the sustainable use of groundwater in this area. The estimated groundwater recharge by the WTF method shows results that are not much different from the previous researchers; however, the city's central and eastern parts have a higher groundwater recharge value than other areas. The infiltration of household wastewater causes higher groundwater recharge in this area from the onsite treatment system using a septic tank. Groundwater recharge from household waste is indicated by the high content of nitrate and E Coli bacteria in groundwater. The use of PDAM water networks in the central and eastern parts also contributes to groundwater recharge.

\section{ACKNOWLEDGEMENTS}

The authors would like to thank the Department of Public Works, Housing, and Energy Mineral Resources of Yogyakarta Special Region Province, Indonesia, for supporting the data. We would also like to thank Mr. Raja Susatio for helping with the maps.

\section{References}

Abdullahi, M.G. and Garba, I. (2015) Effect of Rainfall on Groundwater Level Fluctuation in Terengganu, Malaysia, Journal Remote Sensing and GIS, 4:2.

Ahmad, I.; Tang, D.; Wang, T.F.; Wang, M.; Wagan, B. (2015) Precipitation Trends over Time Using Mann-Kendall and Spearman's rho Test in Swat River Basin Pakistan, Advances in Meteorology 2015:431860, p 15.

Apaydin, A. (2010) Response of Groundwater to Climate Variation: Fluctuations, of Groundwater Level and Well Yields in the Halacli Aquifer (Cankiri, Turkey), Journal Environmental Monitoring Assessment 165:653-663.

Boretti, A. and Rosa, L. (2019) Reassessing the projections of the world water development report, Npj Clean Water, 2(1): 1-6.

BPS-Statistics of Yogyakarta City (2018) Yogyakarta City in Figure 2017, BPSStatistics of Yogyakarta City, p 424.

Cai, Z. and Ofterdinger, U. (2016) Analysis of Groundwater -level Response to Rainfall and Estimation of Annual Recharge in Fractured Hard Rock Aquifers, NW Ireland, Journal of Hydrology, 535: 71-84.

Crosbie, R.S.; Binning, P., and Kalma, J.D. (2005) A Time Series Approach to Inferring Groundwater Recharge using the Water Table Fluctuation Method, Water Resources Research, 41: 1-9.

Dinka, M.O.; Loiskandl, W.; Furst, J.; Ndambuki, J.M. (2013) Seasonal Behavior and Spatial Fluctuations of Groundwater 
Levels in Long-Term Irrigated Agriculture: the Case of a Sugar Estate, Pol. J. Environ. Stud., 22(5): 1325-1334.

Endo, N.; Matsumoto, J., and Lwin, T. (2009) Trends in Precipitation Extremes over Southeast Asia, SOLA, 5: 168-171.

Fathmawati, F.; Fachiroh, J.; Sutomo, A.H.; Putra, D.P.E. (2018) Origin and Distribution of Nitrate in Water Well of Settlement Areas in Yogyakarta, Indonesia, Environ Monit Assess 190: 628.

Gatto, E. and Lanzafame, M. (2005) Water Resource as a Factor of Production: Water Use and Economic Growth, Paper presented at the 45th ERSA Conference, Amsterdam, $p$ 20.

Gilbert, R.O. (1987) Statistical Methods for Environmental Pollution Monitoring, Van Nostrand Reinhold Company In., New York, USA, p 320.

Healy, R.W. and Cook, P.G. (2002) Using Groundwater Levels to Estimate Recharge, Hydrogeology Journal, 10:91-109.

Lutz, A.; Minyila, S.; Saga, B.; Diarra, S.; Apambire, B.; Thomas, J. (2015) Fluctuation of Groundwater Levels and Recharge Patterns in Northern Ghana, Climate, 3: 1-15.

Mac Donald and Partners (1984) Greater Yogyakarta Groundwater Resources Study, Volume 3: Groundwater. Directorate General of Water Resources Development Project (P2AT), Ministry of Public Works, Government of the Republic of Indonesia, $p$ 116.

Manna, F.; Murray, S.; Abbey, D.; Martin, P.; Cherry, J.; Parker, J. (2019) Spatial and Temporal Variability of Groundwater Recharge in a Sandstone
Aquifer in a Semiarid Region, Hydrol. Earth Syst. Sci., 23: 2187-2205.

Manny, L.; Atmaja, R.R.S.; Putra, D.P.E. (2016) Groundwater Level Changes in Shallow Aquifer of Yogyakarta City, Indonesia: Distribution and Causes, Journal of Applied Geology, 1(2): 89 -99.

Meteorological, Climatological, and Geophysical Agency of Indonesia (BMKG) (2018) Rainfall Data of Yogyakarta City from 2011 to 2017, BMKG, p 22. (Unpublished)

Mohammad, A.H.; Shatanawi, K.; Odeh, T. (2016) A Modified Modeling of Potentiality and Vulnerability of the Groundwater Resources in Amman Zarqa Basin, Jordan, Kuwait J. Sci. 43(1): 208-221.

Pohlert, T. (2016) Trend: Non-Parametric Trend Test and Change-Point Detection. R Package Version 0.1.0. https://CRAN.Rproject.org/package=trend.

Putra, D. P. E. (2007) The Impact of Urbanization on Groundwater Quality; a Case Study in Yogyakarta City-Indonesia. Mitteilungen zur Ingenieurgeologie und Hydrogeologie, heft 96, Ph.D. thesis, Rheinisch-Westfalische Technische Hochschule Aachen, Germany, p 147.

Salmi, T.; Määttä, A.; Anttila, P.; Airola, T.R.; Amnell, T. (2002) Detecting Trends of Annual Values of Atmospheric Pollutants by The Mann-Kendall Test and Sen's Slope Estimates -The Excel Template Application Makesens, Ilmanlaadun Julkaisuja Publikationer Om Luftkvalitet Publications on Air Quality No. 31, Ilmatieteen Laitos Meteorologiska Institutet Finnish Meteorological Institute, Helsinki, Finland, p 35.

Scanlon, B.R.; Healy, R.W.; Cook, P.G. (2002) Choosing Appropriate Techniques for 
Quantifying Groundwater Recharge, Hydrogeology Journal, 10:18-39.

Sophocleous, M. (1991) Combining Soil Water Balance and Water Level Fluctuation Methods to Estimate Natural Ground-water Recharge: Practical Aspects. Journal of Hydrology, 124: 229-241.

Varni, M.; Comas, R.; Weinzettel, P. and Dietrich, S. (2013) Application of the Water Table Fluctuation Method to Characterize Groundwater Recharge in the Pampa Plain, Argentina, Hydrological Sciences Journal Journal des Sciences Hydrologiques, 58(7): 1445-1555.

Vasconcelos, V.V.; Koontanakulvong, S.; Suthidhummajit, C.; Junior, P.P.M.; Hadad, R.M. (2017) Analysis of SpatialTemporal Patterns of Water Table Change as a Tool for Conjunctive Water Management in the Upper Central Plain of the Chao Phraya River Basin, Thailand, Appl Water Sci 7:245-262.

Velis, M.; Conti, K.I. and Biermann, F. (2017) Groundwater and Human Development: Synergies and Trade-offs within the Context of the Sustainable Development Goals, Sustain Sci. 12(6): 1007-1017.

Wilopo, W.; Putra, D.P.E.; Setiawan, H.; Setyawan, K.D. (2020) Impact Assessment of Apartment Building Foundation to Terban Spring Discharge, Yogyakarta City, Journal of Degraded and Mining Lands Management, 7(3): 2111-2122.

Wilopo, W.; Putra, D.P.E.; Hendrayana, H. (2021) Impact of Precipitation, Land Use Change and Urban Wastewater on Groundwater Level Fluctuation in the Yogyakarta-Sleman Groundwater Basin, Indonesia, Environ Monit Assess 193: 76.
Winter, T.C.; Harvey, J.W.; Franke, O.L.; Alley, W.M. (1998) Groundwater and Surface Water - a single resources, US Geological Survey, Circ. 1139, p 87.

UNESCO World Water Assessment Programme (WWAP) (2019) The United Nations World Water Development Report 2019: Leaving No One Behind. Paris, UNESCO. p 186.

Zhou, Y.; Xiao, W.; Wang, J.; Zhao, Y.; Huang, Y.; Tian, J.; Chen, Y. (2016) Evaluating Spatiotemporal Variation of Groundwater Depth/Level in Beijing Plain, a Groundwater-Fed Area from 2001 to 2010, Advances in Meteorology 2016, Article ID 8714209, p 11.

$\begin{array}{ll}\text { Submitted } & : 23 / 03 / 2020 \\ \text { Revised } & : 10 / 07 / 2020 \\ \text { Accepted } & : 05 / 08 / 2020 \\ \text { DOI } & : 10.48129 / \text { kjs.v48i2.9397 }\end{array}$

